\title{
PEDAGOGICAL MODELING OF DEVELOPMENT OF PROFESSIONAL CULTURE OF MILITARY DOCTORS IN THE SYSTEM OF MILITARY MEDICAL EDUCATION
}

\author{
ПЕДАГОГІЧНЕ МОДЕЛЮВАННЯ РОЗВИТКУ ПРОФЕСІЙНОЇ \\ КУЛЬТУРИ ВІЙСЬКОВИХ ЛІКАРІВ У СИСТЕМІ ВІЙСЬКОВО- \\ Lecturer \\ Володимир ШПОРТЬКО, \\ викладач
}

Volodymyr SHPORTKO,

\author{
volodimir2000@yahoo.com \\ https://orcid.org/0000-0002-0805-4922 \\ Ukrainian Military Medical Academy Українська військово-медична \\ академія \\ 45/1 Moskovska St., \\ Kyiv, 01015 \\ вул. Московська, 45/1 \\ Original manuscript received: October 12, 2020 \\ Revised manuscript accepted: December 09, 2020
}

\begin{abstract}
The article outlines and substantiates the most important conditions for the development of professional culture of military doctors. The author's methods of formation of professional culture and its pedagogical modeling in the process of training future military doctors in the system of medical universities of Ukraine is determined. The relevance of the study of the professional culture of future military doctors is associated with the growing role of military doctors, given the continuation of the Russian - Ukrainian war and the spread of infectious diseases.

It's noted that professional culture, as a social-psychological component, is inherent in the relevant professional environment and determines the professional, moral and psychological qualities of the of the individual, the appropriative level of training of military doctors. For the development of the professional culture of future military doctors it's necessary to apply the appropriate pedagogical technology, to create the necessary pedagogical conditions using the model subject - activity learning of students.

When applying the author's method of forming the professional culture of military doctors in the system of military medical educations, the author proposes to use optimal forms and methods of teaching, motivate students, and intensify practical training.

Pedagogical conditions are considered as a set of systematic pedagogical circumstances created by lecturers in medical universities for purposeful practical training of future military doctors. Pedagogical conditions include such aspects of practical training as a motivational-value, methodological, theoretical, praxiological, evaluative and reflexive.
\end{abstract}

Key words: professional culture, pedagogical conditions, pedagogical modeling, pedagogical technology, future military doctors.

Introduction. The training of military doctors is extremely relevant, due to problems the rapid spread of infections pandemic, the continuation 
Russian-Ukrainian war and requires a qualitative update of training, development and improvement of forms, methods of training and professionaloriented model of professional culture of military doctors. The military-political situation pushed the country`s leadership to complete and adopt in 2028 a new military medical doctrine and creation in early 2020 of Command of the Medical Forces of the Armed Forces of Ukraine. Research of problem of development of professional culture of future military doctors' aims to identify the state of development of the problem of formation of professional culture of future military doctors in pedagogical theory and practice in the system of higher medical institutions; theoretically improve the structure and content of professional culture, to substantiate the criteria of its formation, to determinate the indicators and levels of formation of future military doctors.

The article clarifies the category of "professional culture of the future military doctor" which is a set of knowledge, skills, abilities, values, moral and behavioral norms, ideological beliefs and professional worldview and based on the general culture of the individual.

The development of the professional culture of the future doctor is impossible without the creation of favorable pedagogical conditions, which cover the main aspects of the pedagogical process in medical universities. Under the pedagogical conditions of formation of professional culture of doctors we understand the corresponding favorable conditions in the system of military medical education, which are created during the educational and pedagogical process.

The professional training of future specialists has been the object and subject of research of scientists in recent years. Defining the pedagogical conditions for the training of future military doctors requires clarification of the concept of "pedagogical conditions".

Modern research in the field of pedagogy interprets quite broadly the term "pedagogical conditions", which relate to various aspects and components of the learning process. The works of V. Andreev, V. Belikov, A. Galeev, S. Goncharenko, O Gura, K. Dubich, M. Zvereva, A. Zubko, N. Kuzmina, A. Lytvyn, I. Pidlasny S. Rubishtein, V. Yagupov are devoted to the problem of determining pedagogical conditions.

The term "pedagogical conditions" is actively used in scientific publications, dissertations and scientific and pedagogical literature. Most encyclopedias, dictionaries, including pedagogical, do not give an equally clear definition of the category "pedagogical conditions". The philosophical interpretation of the category "condition" is reduced to the expression of a complex of objects (things, their states and interactions) and a certain environmental phenomenon (object), without which it cannot exist. The explanatory dictionary of the modern Ukrainian language specifies the concept of "condition", namely, as - a necessary circumstance that allows the implementation, formation of something or contributes to something, as a factor, the driving force of any process, phenomenon (Busel, 2005). In the "Dictionary-Handbook of Professional Pedagogy" (2006) pedagogical 
conditions are defined as the circumstances on which depends the productivity of a holistic pedagogical process of professional training, mediated by the activity of the individual, a group of people (Semenova, 2006).

There are many approaches in determining the pedagogical conditions depending on the different areas of application. For example, taking into account the theory of causation, the conditions include the cause, which generates a certain phenomenon, which is characterized by greater activity of influence, relative independence of action and other characteristics (Phil. Encyclopedia, 1992). As a psychological phenomenon, "condition" is understood as a set of phenomena of the external and internal environment that probably affect the development of a particular phenomenon, which is mediated by the activity of an individual or group of persons (Konuhov, 1992).

K. Dubych, leads the concept of "pedagogical conditions", cites as a set of interdependent and interdependent measures of the pedagogical process, which ensure the achievement of a specific goal (Dubith, 2007: 267). N. Zhytnyk, researching pedagogical conditions, leads that they provide quality professional training, namely: the implementation of the content of education, methodological support of the educational process, the introduction of innovative educational technologies, providing a personcentered approach to education, the state of educational work in higher education school, professional skills of teachers (Zhytnyk, 2002:233). Depending on the areas of application and the laws considered, there are different types of conditions: necessary and sufficient, objective and subjective, general and specific. Depending on the areas of application and the laws considered, there are different types of conditions: necessary and sufficient, objective and subjective, general and specific.

Theoretically, there is a great need for scientific understanding of the term "pedagogical conditions" in the context of considering the conditions for the formation of professional culture of future military doctors, due to insufficient development of a certain category in the organizational and pedagogical plane as a direction of research educational system. It is necessary to agree with the opinion of A. Lytvyn who understands the pedagogical conditions as a set of diverse (external and internal) sociopedagogical and didactic factors, necessary and sufficient for the emergence and rational sustainable functioning of a particular pedagogical system (Lytvyn, 2010: 65). Pedagogical conditions ensure the integrity of education and upbringing in the information and educational environment of the institution in accordance with the requirements of society and the demands of the labor market, promote comprehensive harmonious development of the individual and create favorable opportunities to identify its talents, take into account needs and form important human and professional qualities, general and professional competencies (Lytvyn, 2014).

At the same time, pedagogical conditions are subject to regulation, which is recognized by most researchers. Depending on the pedagogical interaction, they increase or hinder the achievement of professional training. Pedagogy, to be an effective source of knowledge, an effective factor in creating productive 
interpersonal relationships in educational systems requires a clear and consistent definition and adherence to the methodological principles of its operation (Viasanovith, 2013). Among scientific researches pedagogical conditions are more often distinguished as: didactic, psychological-pedagogical, organizational-pedagogical and social-pedagogical.

Given the fact that in the system of military medical education the effectiveness of training depends on the organization of the educational process, the effectiveness of both general medical departments and departments of military-professional direction, gradual training, efficiency of pedagogical teams there is an urgent need to consider organizational and pedagogical conditions professional culture of future military doctors.

The purpose of the article is to determine and substantiate the organizational and pedagogical conditions for the development of professional culture of military doctors, their modeling in the system of military medical education.

Research methods and techniques. The analysis of scientific literature, comparison, classification, generalization and systematization of the material were used in solving the research tasks.

Results and discussions. The concept of "pedagogical technology" is widely covered in the pedagogical literature. This is reflected in the works of such scientists as A. Capska, P. Samoilenko, P. Podkasistyi, M. Levkivsky. The implementation of pedagogical technologies in the educational process contributes to the activities of the teacher, determines the ways to achieve the goal, management of the learning process. In the training of military doctors, the use of pedagogical technologies allows to move to the predicted final result at successive stages of training. We must agree with the opinion of $\mathrm{V}$. Ortynsky that pedagogical technologies should be considered as a systematic and consistent implementation in practice of a pre-designed learning process, as a system of ways and objectives to manage this process (Ortynsky, 2009). Pedagogical technology is a complex integrated system that contains information-subject and procedural aspects aimed at mastering systematized knowledge, acquired professional skills of forming personal qualities of students, set learning goals .

V. Slastyonin shows pedagogical technology as an ordered set of actions, operations and procedures that provide a diagnosed and predicted result in a constantly changing educational process (Slastyonin, 2000).

Pedagogical technologies are classified: by the level of use of pedagogical technologies, by philosophical basis, by orientation on personal structures, by the leading factor in the development of the psyche and others. Most scientists share the view of the structure of pedagogical technology. This structure distinguishes the basic interconnected components, including conceptual, substantive and procedural.

During the study of the problem of professional culture of future military doctors we have developed pedagogical technology of its formation, which we define as a specially organized system of pedagogical conditions, 
forms, methods and tools aimed at forming professional culture of future military doctors in the process of professional training.

Pedagogical technology, which is developed for the formation of professional culture in future military doctors in the process of their training in medical universities provides the following structural components:

1. Study and analysis of curricula, content of educational programs and disciplines for the formation of professional culture.

2. Selection and selection of optimal forms and methods of teaching in order to form a professional culture.

3. Motivating the student to work independently as an important means of forming a professional culture.

4. Intensification of practical professional training.

5. Involvement of students in practical work in medical institutions and hospitals in order to form a professional culture in them.

6. Pedagogical diagnosis of the level of formation of professional culture in future military doctors.

The dictionary-reference book on professional pedagogy states that pedagogical conditions are the circumstances under which there is a holistic productive pedagogical process of professional training, which is mediated by the activity of the individual, a group of people (Marhadeeva, 2002).

Academician S. Goncharenko understands the term "pedagogical conditions" as a demonstration of a set of relations processes necessary for the emergence and existence of a particular object or circumstances of the learning process, which are the result of selection, design and adaptation of elements , content, methods, teaching aids to achieve goals (Goncharenko, 1997).

Having analyzed the definition of "pedagogical conditions" covered in pedagogical theory, we define them as a set of organizational and pedagogical measures aimed at achieving a high level of professional culture in future military doctors in the learning process. The pedagogical conditions for the formation of professional culture in future military doctors in the process of their professional training should be determined: increasing their motivation for educational and professional activities, the formation of important professional values; updating the content of educational materials; selection of optimal forms and methods of teaching; practical training and independent work.

Based on the generalization of the results of the theoretical study of the problem of pedagogical technology, the pedagogical conditions are determined, the creation and observation of which ensures the formation of professional culture in future doctors in the process of professional training.

Important pedagogical conditions in this context should be considered: promoting increased motivation for educational, cognitive and professional activities, the formation of important professional values; updating the content of educational materials; selection and selection of optimal forms and methods of teaching; increasing the share of practical training in hospitals and hospitals, independent work of future military doctors according to the methods of teachers. 
We think that the formation of the professional culture of future military doctors in the system of higher medical institutions is possible through the application of its pedagogical modeling. The method of modeling the formation of professional culture of military doctors in the system of military medical education should be understood as an educational system based on the concept of subject-activity training, which includes effective methods, techniques, techniques and forms used in the main stages of professional culture. Methods of training future doctors can be presented at the level of educational activities, the study of general education, special medical and military disciplines. The method requires proof of relevant knowledge, diagnosis of their assimilation and stimulation of participants in the educational process.

The method of forming the professional culture of military doctors in essence determines the planning of universities aimed at a clear algorithm for creating didactic conditions in teaching, the scientific level in the development of content and methods of teaching, designing pedagogical processes for goals and content, working out methods, techniques, forms and means to achieve learning outcomes as well as the definition of tools in a set of goals, methods, organizational forms that will contribute to the development of professional culture of future doctors.

The method of development of professional culture of future military doctors is a well-founded didactic system with the use of intellectual, operational, organizational and functional, diagnostic components that ensure the performance of their professional tasks.

The method of development of professional culture of doctors is based on problem-based and modular training. The modular system applies the curriculum in the relevant problem areas. In pedagogy, the module is a functional unit of the educational process. Modular training is used in the training of future military doctors. It is a package of scientifically adapted programs for general and individual study, which provides educational achievements of students with different levels of prior training. The educational module aims at the gradual assimilation by students of the system of educational materials with the help of the teacher during the search cognitive process.

Problem-based learning system, in turn, involves the acquisition and assimilation of new knowledge through awareness of theoretical and practical problems, tasks that are modeled and created for this purpose through problem situations. Domestic psychologists T. Kudryavtsev, A. Matyushkin, Z. Kalmykova and others have developed the psychological basis of problem-based learning in its various modifications.

In order to develop the professional culture of future military doctors should use the model of subject-activity training of students, which is proposed by V. Yagupov (Yagupov, 2015:26). This model includes the ability (student) of the listener to self-assess and realize their level of training, their professional qualities, their own activities and themselves as a subject of 
professional activity. The methodology determines the professional orientation aimed at the humanization, democratization and professionalization of the stages, as well as the process of formation of subject-subject relations between teachers and students as subjects of joint activities. The main stages of this technique are: motivational, theoretical, praxiological, evaluative and reflex.

The motivational stage actualizes the positive instruction of the professional culture of the doctor, developing the motivation to perform medical duties. The theoretical stage is aimed at ensuring the fruitful work of teachers and students for the development of professional culture, during which the acquisition of knowledge, achievement of didactic goals. The praxiological stage is designed to acquire and improve practical professional knowledge, skills and abilities in achieving the ability to quality professional activities of future military doctors. Assessment stage - aims to develop students' ability to self-assess their training and practical skills. At the same time, it is the presence of a quality system of assessment of student achievement by teachers, their professional and cultural growth.

During the stage of generalization of educational activity the assessment and systematization of professional, military, deontological knowledge, development of the corresponding algorithm of activity is carried out. Students must acquire the ability to realize their own achievements in the development of their own professional culture. This stage takes place during the period of final attestation of students, as well as assessment of their practical training in military units and hospitals.

Reflexive - assessment of students based on the results of their educational activities and practical activities. At this stage, not only theoretical knowledge is tested, but also the professional competence of the future doctor, the ability to perform duties in the military unit, the possibility of transition from the acquired theoretical knowledge to practical actions. At this stage, the level of development of the components of professional culture, the effectiveness of all training is determined.

The method of formation of professional culture requires the achievement of results in order to form the professional culture of future military doctors. The effective stage or component must be divided into appropriate levels of development of the professional culture of the future military doctor, namely: low, medium and high.

Thus, we substantiated the organizational and pedagogical conditions for the formation of professional culture of military medics in the system of military medical education by analyzing the psychological and pedagogical literature, research, attempted pedagogical modeling of the formation of professional culture of military doctors.

The substantiated model of formation of professional culture of doctors offered by us will allow to develop the optimal approach in the course of development of professional culture in system of higher medical institutions preparing military doctors, to develop the appropriate technique on their preparation, will serve as the basis for improvement of educational 
programs and plans.

Conclusions. The analysis of the materials presented in the article showed that modern research pays great attention to theoretical and applied aspects of the formation of professional culture of medical workers. At the same time, the problem of forming the professional culture of military doctors is insufficiently studied, which requires further study in order to improve the quality system of training future military doctors in higher medical institutions of Ukraine and the Ukrainian Military Medical Academy.

The author's vision of pedagogical technology and creation of pedagogical conditions of development of professional culture of future doctors is stated and substantiated in the article. Based on the analysis of modern scientific research, the author substantiates the pedagogical modeling of the formation and development of professional culture of future military doctors in the system of military medical education.

Conclusions and results of further research on the professional culture of military doctors trained in higher medical institutions of Ukraine will help to create appropriate conditions for optimizing the educational process, moral and psychological support for the training of military doctors in normal everyday conditions. The developed material of the research will also contribute to the consideration of new scientific approaches in the training of students and students of UVMA in the context of the ongoing military conflict and the existing challenges of infectious diseases.

A special place in further research on the development of professional culture belongs to the issues of further adaptation of military medical education of Ukraine to NATO standards, gaining best practices in training, development of new technologies and systems of work with both military doctors and their patients

\section{Література}

Бусел В.Т: Великий тлумачний словник сучасної української мови (з дод. і доповн.). Київ: Ірпінь: ВТФ «Перун», 2005. - 1728 с. ISBN 966-569-013-2

Семенова А.В: Словник-довідник 3 професійної педагогіки. Одеса: Пальміра, 2006. - с. 193. ISBN 966-8945-02-6

Философская энциклопедия // Москва: Академик. - [електронній ресурс.Режим доступу:] dsc.academic.ru/dic.nsf/enc_philosophy/7523

Конюхов Н.І. (1992): Справочник практического психолога. Прикладные аспекты современной психологии. Термины, законы, концепции: справочное издание. 1992.Режим доступу http://www.twirpx.com/file/15704.

Дубич К.В.: Особистісно орієнтоване виховання студентів в умовах соціокультурного середовища вищого навчального закладу: дис. Канд. пед. наук :13.00.07 / Дубич Клавдія Василівна. - Рівне, 2007.-267с.

Житник Н. В: Організаційно-педагогічні умови підготовки бакалаврів економіки у коледжі II рівня акредитації: дис. Канд. пед. наук: 13.00.04 / Житник Н. В.- Кривий Ріг, 2002.-233 с.

Литвин А.В.: Педагогічні умови інформатизації навчально-виховного процесу в ПТНЗ будівельного профілю. Львів: Збірник наукових праць Львівського державного університету безпеки життєдіяльності. Педагогіка і психологія професійної освіти. 2010 - №5. - с. 65-78. 
Литвин А.В.: Методологічні засади «педагогічні умови» на допомогу здобувачам наукового ступеня. Львів: 2014.- СПОЛОМ. 76 с.

Васянович Г.П: Методологічні аспекти педагогічної науки на сучасному етапі ії розвитку. Педагогіка і психологія професійної освіти: науковий пошук, проблеми, перспективи: матеріали науково-практичної конференції (у рамках Всеукраїнського фестивалю науки). Львів: СПОЛОМ. 2013.- с. 7-28.

Ортинський В.Л. Педагогіка вищої школи. Види педагогічних технологій: Електронний ресурс: [режим доступу]: http://pidrucniki.com/17190512/ pedagogika/vidi_pedagogichnih_tehnologiy

Сластьонін В.А.: Педагогічний процес, як система. - Москва.- Вид. Дому Магістр - Прес, 2000, - 488с.

Словарь по социальной педагогике : учеб. пособ. для студ. высш. учеб. заведений / [авт.-сост. Л. В. Мархадаева]. Москва : Академия, 2002. 386 с.

Гончаренко С.В.: Український педагагічний словник. Київ.- 1997.- 376 с.

Яупов В.В.: Професійний розвиток особистості фрахівця: поняття, зміст та особливості. Наукові записки. Том 175. Київ: 2015.- Педагогічні, психологічні науки та соціальна робота. УДК 378.147. с. 26.

\section{References}

Busel V.T. Velikiy nlumathniy slovnik suthasnoi ukrainskoi movi.(z dod. i iz dopovn). Kyiv. Irpin. VTF "Perun”. 2005. -1728 s. ISBN 966-569-013-2.

Semenova A.V. Slovnik-dovidnik z profesiinoi pedagogiki. Odesa. Palmira, 2006. - s. 193. ISBN 966-8945-02.

Filosofskaja ehsiklopedia // Moskva: Akademik. - [Elektronniy resurs] dsc.academic.ru/dic.nsf/enc_philosophy/7523.

Konuhov N.I.: Spravothnik praknitheskogo psihologa. Prikladnie aspekti sovremennoy psihologii. Termini, zakoni, kontsepsii: spravothnoe izdanie. 1992. Rezim dostupu http://www.twirpx.com/file/15704.

Dubith K.V. : Osobisnisno orientovane vihovannia studentiv $v$ umovah sotsiokulturnogo seredovistha vishogo navthalnogo zakladu: dis. Kand. Ped. nauk: 13.00.07 / Dubith Klavdia Vasilivna. - Rivne, 2007.-267 s.

Zhytnyk N.V.: Organozatsiyno-pedagoginni umovi pidgotovki bakalavriv ekonomiki u koledzi II rivnia akreditatsii: dis. Kand. ped. nauk: 13.00.04 / Zhytnyk N.V.- Kriviy Rig, 2002.-233 s.

Lytvyn A.V: Pedagogithni umovi informatsizatsii navthalno-vihovnogo protsesy v PTNZ budivelnogo profily. Lviv: Zbirnik naukovih prats Lvivskogo derjavnogo universitetu bezpeki zitjedijalnosti. Pedagogika I psihologija profesijnoi osviti. 2010 № 5. s. 65-78.

Lytvyn A.V:Metodologihni zasadi "pedagogihni umovi" na dopomogu zdobovutham naukovogo stupenyu. Lviv: 2014.-SPOLOM. 76 s.

Viasanovith G. P. Metodologihni aspekti pedagogihnoi nauki na suthasnomu etapi ii rozvitky. Pedagogika i psihologija profesiinoi osvity: naukovij poshuk, problemi, pespektivi: materiali naukovo-praktihnoi konferensii (u ramkah Vseukrainskogo festivaliu nauki). Lviv: SPOLOM. 2013.-s. 7-28.

Ortynsky V.L. Pedagogika vishoi skoli. Vidi pedagogihnih tehnologii: Ekektronniy resurs [regim dostupu]: http://pidrucniki.com/17190512/ pedagogika/vidi_pedagogichnih_tehnologiy

Slastyonin V.A. Pedagogihniy protses, jak sistema.- Moskva.- Vid. Domy Magistr - Pres, 2000, $-488 \mathrm{~s}$.

Slovar po sotsialnoi pedagogike: uthebnoe posob. dlia stud. vish.uthebn. zavedeniy [avtor-sost. L.V.Marhadeeva]. Moskva: Akademia, 2002. 386 s.

Gontharenko S.V. Ukrainskiy pedagogihniy slovnik. Kyiv.- 1997. 376 s. 
Yagupov V.V. Profesiyniy rozvitok osobististi fahivtsi: poniattia, zmist ta osoblivosti. Naukovi zapiski / Tom 175. Kyiv. 2015.- Pedagoginni nauki ta sosialna rodota. UDK 378.147. s. 26.

\section{АНОТАЦІЯ}

У статті викладено і обгрунтовано найбільш важливі умови розвитку професійної культури військових лікарів. Наведена авторська методика формування професіональної культури та ї педагогічне моделювання у процесі навчання майбутніх військових лікарів в системі медичних університетів України. Актуальність дослідження професійної культури майбутніх військових лікарів пов'язана із зростанням ролі військових лікарів, зважаючи на продовження російсько-української війни і поширенням пандемії COVID - 19.

Зазначається що професійна культура, як сочіально-психологічний компонент, притаманний відповідному професійному середовищу $і$ визначає професійні, морально-психологічні якості особистості, відповідний рівень професійної підготовки військового лікаря. Для розвитку професійної культури майбутніх військових лікарів необхідно застосовувати відповідну педагогічну технологію, створити необхінні педагогічні умови із використанням моделі суб'єктно-діяльнісного навчання студентів.

При застосуванні авторської методики фрормування професіональної культури військових лікарів у системі військово-медичної освіти автор пропонує застосовувати оптимальні форми і методи навчання, мотивувати студентів, інтенсифікувати практичну професійну підготовку.

Педагогічні умови розглядаються як сукупність системних педагогічних обставин, які створюються педагогами у медичних університетах для цілеспрямованої практичної підготовки майбутніх військових лікарів.

3 метою розвитку професійної культури майбутніх лікарів слід використовувати модель суб'єктно-діяльнісного навчання студентів. Головними етапами методики є мотиваційний, теоретичний, праксиологічний, оцінювальний і рефрлекторний.

Ключові слова: профресійна культура, педагогічні умови, педагогічне моделювання, педагогічна технологія, майбутні військові лікарі. 